研究

\title{
金属射出成形材へのマイクロオーダー微細溝の圧印加工
}

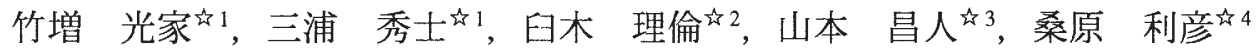 \\ 的1 九州大学大学院工学研究院知能機械システム部門, = 819-0395 福岡市西区元岡 744. \\ 的 九州大学大学院工学府知能機械システム専攻, 厂 819-0395 福岡市西区元岡 744. \\ 的 3 東京農工大学大学院工学教育部機械システム工学専攻, $\%$ 184-8588 小金井市中町 2-24-16. \\ 44 東京農工大学大学院共生科学技術研究部物質機能科学部門, $\overline{1}$ 184-8588 小金井市中町 2-24-16.
}

\section{Coining of Microgrooves on Injection Molded Materials}

\author{
Teruie Takemasu ${ }^{\text {is } 1}$, Hideshi Miura ${ }^{\text {is } 1}$, Tadanori Usuki is 2 , \\ Masahito Yamamoto ${ }^{\text {th } 3}$ and Toshihiko Kuwabara ${ }^{\text {is } 4}$ \\ ${ }^{2}$ 1 Dept. Intelligent Machinery and Systems, Kyushu University, 744 Motooka, Nishi-ku, Fukuoka 819-0395, Japan. \\ ${ }^{2}{ }^{2}$ Dept. of Intelligent Machinery and Systems, Graduate School of Kyushu University, 744 Motooka, Nishi-ku, Fukuoka 819-0395, Japan. \\ ${ }^{23}$ Dept. Mech. Systems Eng., Graduate School of Tech., Tokyo University of Agriculture and Tech., \\ 2-24-16 Naka-cho, Koganei 184-8588, Japan. \\ ${ }_{4}^{4}$ Div. Adv. Mat. Sci. and Tech., Inst. Symbiotic Sci. and Tech., Tokyo University of Agriculture and Tech., \\ 2-24-16 Naka-cho, Koganei 184-8588, Japan.
}

Received May 12, 2006

\section{SYNOPSIS}

The final objective of this study is to establish the optimized manufacturing method of herringbone microgrooves for fluid dynamic spindles. In this article, two kinds of fundamental coining experiments of a simple indentation are carried out to create microgrooves of $5 \sim 10 \mu \mathrm{m}$ depth. In order to compare the coining performance, two kinds of materials are used. One is an austenitic stainless steel (SUS303) of the wrought material and the other is also an austenitic stainless steel (SUS304L) of metal injection molded (MIM) material which has 5\% porosity. In experiment-1, a flat head punch with three micro projections of $10 \mu \mathrm{m}$ height is pushed into a hexahedral specimen with or without the ultrasonic vibration. The groove depth of the MIM material increases in proportion to the punch load in the static indentation and its maximum value is about $80 \%$ larger than that of the wrought material. The imparting of the ultrasonic vibration is effective to increase the amount of groove depth especially for the MIM material under the lower punch load. In experiment-2, a circular punch and a circular anvil are statically pushed into a cylindrical specimen to produce 18 parallel grooves with an equal pitch in the circumferential direction. The groove profiles become almost uniform and the burr formation at tips of groove shoulder is effectively suppressed under the excessive amount of die indentation.

KEY WORDS

coining, indentation, microgrooves, injection molded material, fluid dynamic spindle

\section{1 緒言}

情報通信機器の集積化・小型化が急速に進んでいる.この ためハードディスクに代表されるデータ入出力用機器に用い られるスピンドルモータも, より一層の小型化・高速化が求 められている. 従来使用されてきた玉軸受は, 現在ではほと んど流体動圧軸受 (以後, FDB と呼ぶ)に置き換わっており, これはFDBが玉軸受に比べ構造が単純でコンパクトであり, またスピンドル軸を流体を介して保持するため長寿命, 低騒 音で耐衝撃性にも優れるためである.FDBには, スピンドル
軸または軸受の表面に Fig.1に示すような媣さ数 $\mu \mathrm{m}$ のV字形 状の微細溝(一般にヘリングボーン溝と呼ばれる)が円周方向 に等ピッチに付けられており,これらがスピンドル回転中の 摺動面の相対運動により動圧を発生する ${ }^{1,2)}$.

ところで, 現在 FDB 用のスピンドル素材は機械加工によ り, V 字形状微細溝は切削, 放電加工および電解エッチング などにより加工されているが，これらはいずれも時間がかか り高コストである.このためFDBスピンドル自体をより高能 率, 高精度かつ低コストに大量生産するための方法が強く求 


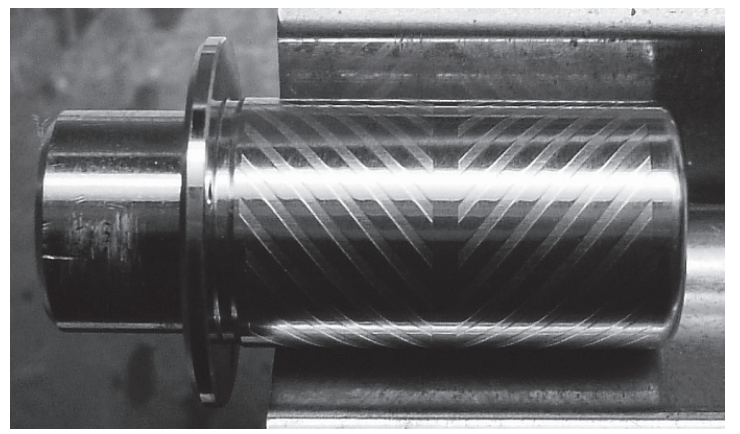

Fig.1 Example of herringbone microgrooves on a FDB spindle.

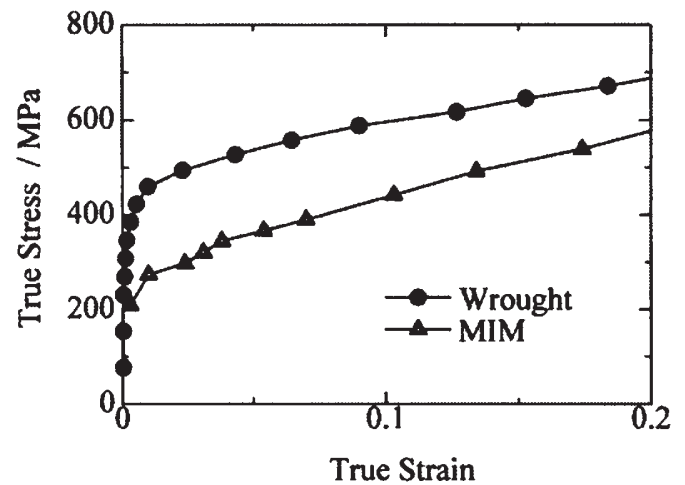

Fig.2 Compressive true stress - true strain curves for two kinds of materials.

められている，金属粉末射出成形 (以後, MIM と呼ぶ) は小 型の複雑形状部品をネットシェープで量産できる ${ }^{3)}$ た, ス ピンドル素材の生産には非常に適した製造法だと考えられる. しかし，微細溝は深さが $2 \sim 10 \mu \mathrm{m}$ と使用する金属粉末粒径 と同程度かそれよりも小さいため,これをMIMのみで高精度 に成形することは困難である，一方，マイクロオーダーの微 細溝を高精度かつ高能率に加工するための方法として, 貨幣 の製造などに用いられる圧印が一般的に最も有力だと思われ る4). また, MIM 材は内部に気孔を有しているため, 通常の 溶製材に比べ圧印による微細溝の形状転写性は良好であると 考えられる. したがって，MIM とマイクロ圧印の組合せは， FDB用スピンドルの製造方法として非常に理想的な技術とな る可能性が高い.

そこで本報では上記のことを確かめるために, 単純押込み による二種類の圧印加工基礎実験を行った，材料には約 $5 \%$ の気孔率を有するステンレス鋼のMIM材, およびそれとほぼ 同一成分の溶製材を用い, 成形された溝形状等から材料の違 いが微細溝の成形性におよぼす影響を調査, 評価した。

\section{2 実験方法}

\section{1 素材}

素材として現状の動圧軸受に使用されている市販のSUS303 (以後，溶製材と呼ぶ) および金属射出成形により作製した

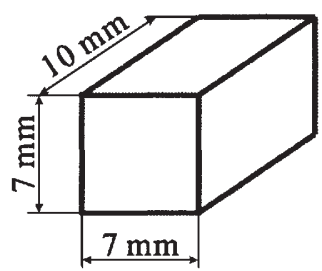

(a)

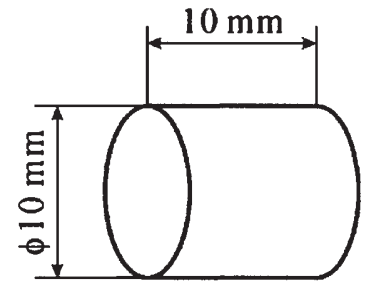

(b) (a) Hexahedral specimen used in Experiment-1

(b) Cylindrical specimen used in Experiment-2

Fig.3 Shapes and dimensions of materials.

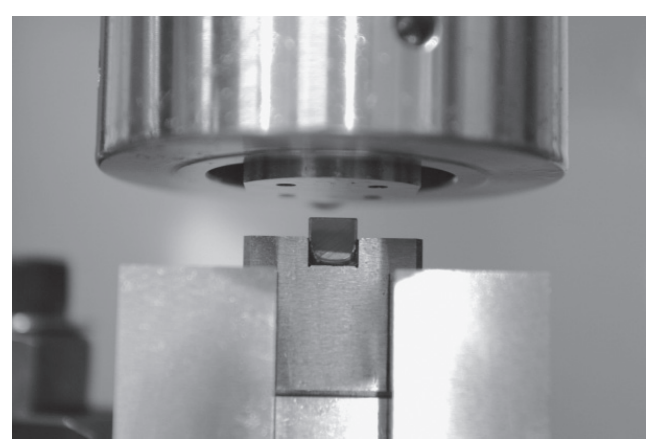

Fig.4 External view photograph of the experimental apparatus.

SUS304L (以後, MIM材と呼ぶ)を用いた. MIM材のステン レス鋼原料粉末(ATMIX社製)の平均粒径は7.86 $\mu \mathrm{m}$ であった. 焼結後の気孔率は約 $5 \%$ であった. Fig.2 に圧縮試験により得 られたそれら素材の真応力ー真ひずみ線図の比較を示す. MIM材は溶製材に比べ降伏応力が約 $50 \%$ 低下している. 平均 硬さは溶製材が HV300, MIM材が HV230であった. Fig.3に 二種類の圧印加工実験に使用した直方体素材(実験-1)と円柱 状素材 (実験-2)の形状と寸法を示す.いずれの素材も被加工 面は研削加工し $\mathrm{Ra}<0.3 \mu \mathrm{m}$ になるよう仕上げた.

\section{2 装置および条件}

Fig.4に二種類の押込み圧印加工実験に使用した装置の加工 部外観を示す。いずれの実験も同一の装置を用い, 二次元平 面ひずみ状態で行われた. Fig.5に実験-1の加工方法を示す. これは微細突起のついた平頭パンチを直方体素材に押込む基 礎実験であり, MIM材と溶製材の材質の違いや超音波振動の 有無が微細溝の成形性におよぼす影響を比較調査するもので ある. 超音波振動付加の狙いは, 実際の動圧スピンドルの微 細溝加工でそれを付加することにより低いパンチ荷重でより 深い溝を成形できれば, 円柱状素材の全体的な塑性変形が抑 制され，真円度等の形状精度を維持できることにある. 具体 的な加工手順は以下の通りである. (a)直方体素材をアンビル 枠内に置き, 上方に平頭パンチを配置する. 平頭パンチ表面 には高さ $10 \mu \mathrm{m}$, 幅 $0.59 \mathrm{~mm}$ の 3 本の微細突起が $2.36 \mathrm{~mm}$ ピッ チで平行についている.これらは実際に使用されている動圧溝 


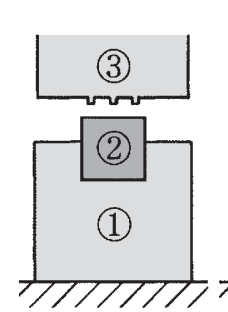

(a)

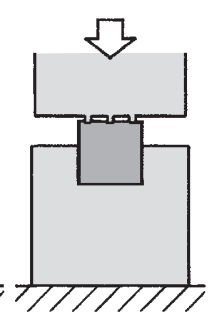

(b)

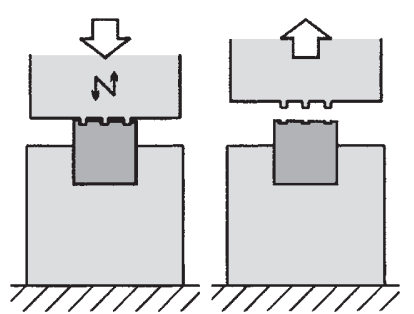

(c) (d)
(1) Anvil, (2) Hexahedral specimen, (3) Punch

Fig.5 Sketch of the experimental procedure in Experiment-1.

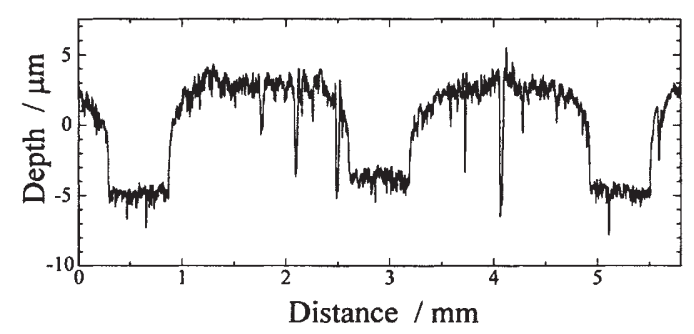

Fig.6 Sample of microgroove profiles after the simple indentation test.

の形状及びピッチ間隔から算出した. (b)パンチを規定の荷重 で試料に押込み圧印加工を行う。パンチ荷重は $5 \mathrm{kN} \sim 20 \mathrm{kN}$ の範囲で段階的に変化させた. (c)押込久荷重を維持したまま パンチ押込み方向に超音波振動を付加する. 付加時間は 0.0 秒 (無付加), 0.3 秒, 0.6 秒, 1.0 秒の 4 通りに変化させた. 超 音波発信器怙有振動数 $20 \mathrm{kHz}$, 出力 $2 \mathrm{~kW}$ のもの用い, パ ンチ先端の振幅は無負荷の自由振動状態で約 $11 \mu \mathrm{m}$ であった. 最後に, (d)パンチを上方へ移動し除荷する. 加工後にはFig.6 に示すような 3 本の微細溝が成形されるが, 両端の溝は材料 の端面ダレのため形状が不安定になるので,ここでは中央の 溝形状から圧印加工性を評価した. 溝形状は小坂式表面粗さ 計 (SE3500) を用いて測定した.

Fig.7 に実験 -2 の加工方法を示す。この実験では双方に微 細突起の付いた円弧角 $120^{\circ}$, 円弧半径 $5.0 \mathrm{~mm}$ の円弧アンビル と円弧パンチを用い, その間に円柱状素材をはさみ静的押込 みを繰り返し行い, 素材円周上に等ピッチの微細溝を成形す る. 目的はこの種の単純押込みがFig.1に示すような円柱状素 材へのヘリングボーン微細溝の成形に応用できるかどうか調 べることである. 加工手順は以下の通りである. (a) 実験-1の 場合と同様円柱状素材を円弧状の溝をもつアンビル上に置き, 上方にアンビルと同じ円弧溝をもつパンチを配置する. パン チおよびアンビルの円弧溝表面には高さ $10 \mu \mathrm{m}$, 幅 $0.50 \mathrm{~mm}$ の 3 本の微細突起が $1.745 \mathrm{~mm}$ のピッチで平行についている. (b) パンチを規定の荷重で試料に静的に押込み圧印加工を行う. (c)パンチを上方へ移動させ，一旦除荷する. (d) 素材を時計 方向に 60 度回転させる. 上記 (a) (d) の手順をさらに 2 回繰

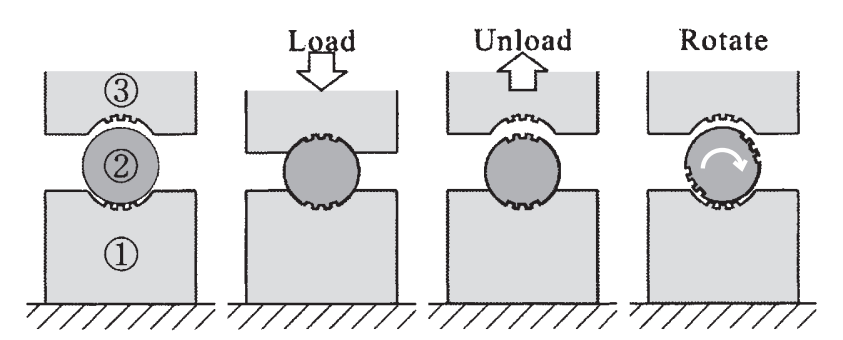

(a)

(b)

(c)

(d)

Fig.7 Sketch of the experimental procedure in Experiment-2.

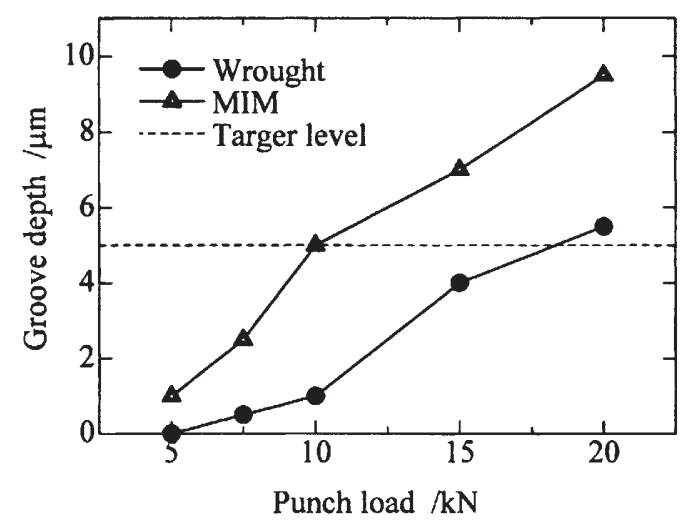

Fig.8 Relationship between groove depth and punch load.

り返す.これにより加工後18本の平行溝が円周方向にほぼ等 ピッチに成形される，溝形状は Rank Taylor Hobson 製真円度 測定機 (Talyrond30) を用いて測定した.

\section{3 実験結果および考察}

3.1 実験 -1

Fig.8に平頭パンチを静的に押し込んだとき中央に成形され た溝の深さとパンチ荷重の関係を, Fig.9に各パンチ荷重にお いて成形された溝形状の比較を各々示す.この加工では目標 溝深さを $5 \mu \mathrm{m}$ 以上とした.これは実際に使用されているこの サイズのFDBの平均的溝深さに相当する.これらの図より材 料の違いによる差異が明確に現れている.まず溶製材の場合 にはパンチ荷重が $10 \mathrm{kN}$ までは試料表面の粗さが若干つぶれ る程度で, ほとんど溝は成形されていない.ところがパンチ 荷重が $10 \mathrm{kN}$ 超えると急に溝深さが増加し, $20 \mathrm{kN}$ では目標 值の $5 \mu \mathrm{m}$ に達している. 一方, MIM 材の場合には溝深さは パンチ荷重にほぼ比例して增加している. 詳細には, パンチ 荷重が $7.5 \mathrm{kN}$ から既に明確な溝がつきはじめ, $10 \mathrm{kN}$ で既に 目標值に達し, $20 \mathrm{kN}$ では溝深さは平頭パンチにつけた微細 突起の高さと同等になっている. ただし, 素材や加工荷重に よらず溝肩部における材料の局部的な隆起は観察されず, む しろその部分ではだれが生じていた.だれ量はMIM材の方が 

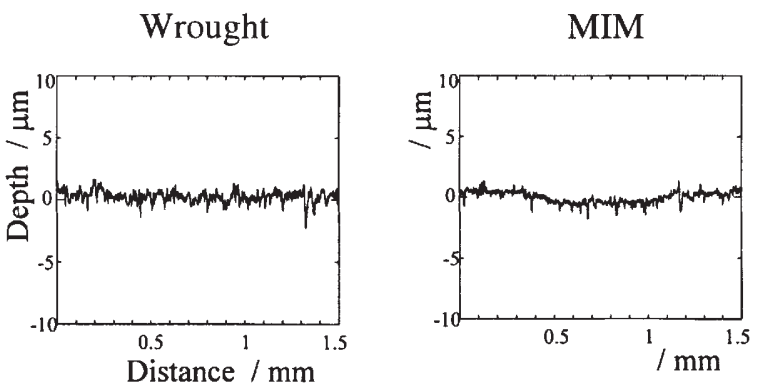

(a) $5 \mathrm{kN}$
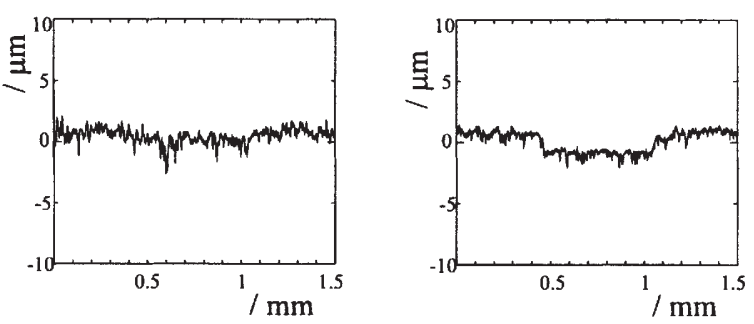

(b) $7.5 \mathrm{kN}$
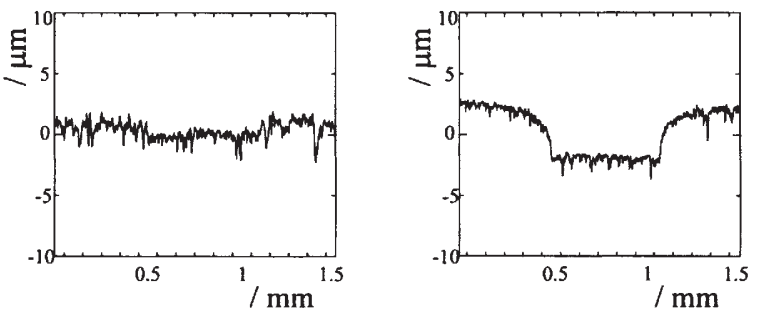

(c) $10 \mathrm{kN}$
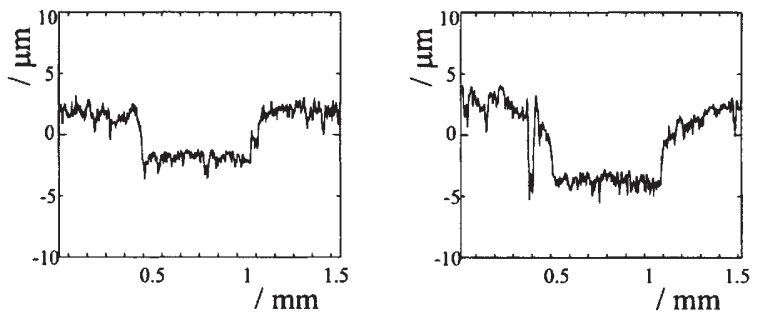

(d) $15 \mathrm{kN}$
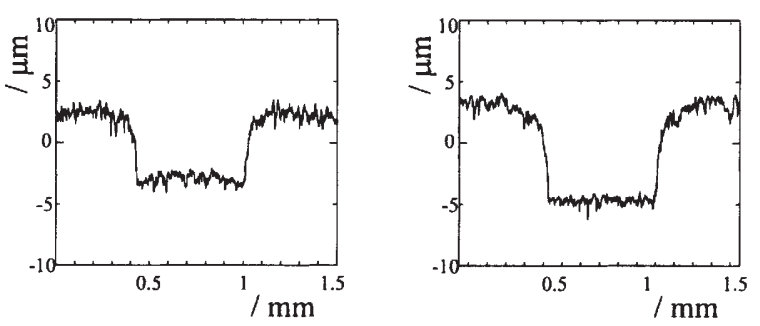

(e) $20 \mathrm{kN}$

Fig.9 Comparison of representative groove profiles in the static indentation test.

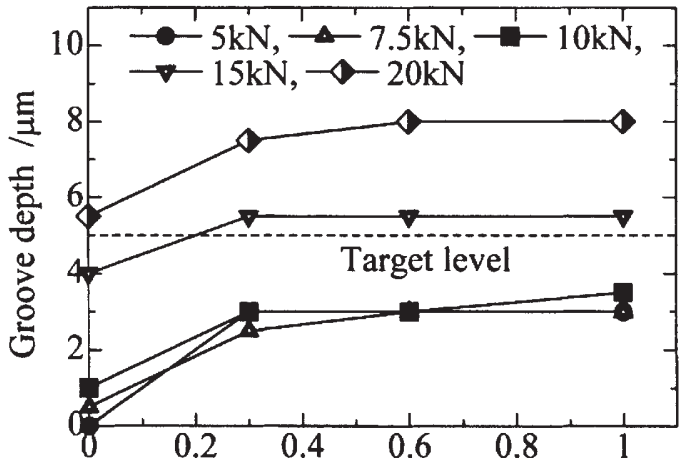

Imparting time of ultrasonic vibration /sec

(a) Wrought materials

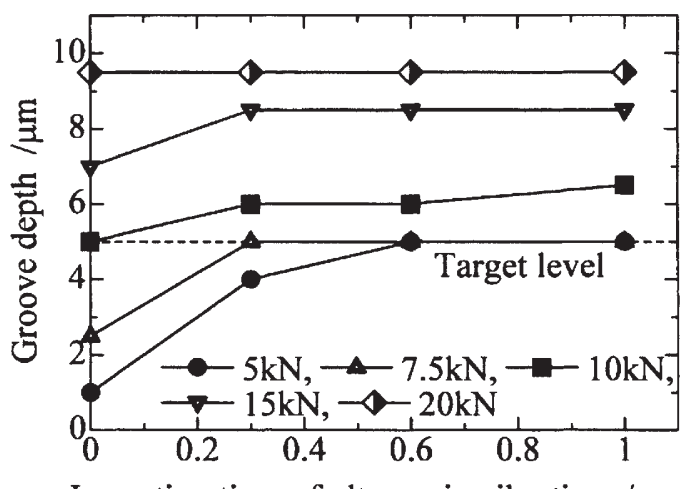

Imparting time of ultrasonic vibration /sec

(b) MIM materials

Fig.10 Relationship between groove depth and imparting time of the ultrasonic vibration.

溶製材に比べ大きくなる傾向が見受けられ，これはMIM材が 内部に多数の気孔を含有するので, 塑性体積一定の条件が緩 和され，いわゆるパイリングアップ現象が抑制されたためで ある。

次に超音波振動付加の効果を検証する. Fig.10(a) と (b)に 各素材におけるパンチ荷重ごとの溝深さと超音波振動付加時 間の関係を示す. また, Fig.11に超音波振動を 0.3 秒付加した ときの溝形状の比較を示す. Fig.10より全体的傾向として, 素 材やパンチ荷重によらず超音波振動を付加することにより溝 深さは増加する傾向にあるが, 付加時間を長くしても増加量 はほとんど変化していない. 詳細に観察すると, Fig.10(a)よ り溶製材の場合には, 増加量はパンチ荷重が $5 \mathrm{kN}$ のきだけ 約 $3 \mu \mathrm{m}$ とやや大きいが，他のパンチ荷重では約 $2 \mu \mathrm{m}$ とほぼ 一定であり, そのため $5 \mathrm{kN}$ の溝深さは $7 \mathrm{kN}$ の溝深さをわず かに逆転している. 一方, Fig.10 (b)より MIM 材の場合には パンチ荷重が大きくなるにつれ増加量は明らかに減少してい る. その理由は, 一般に超音波振動の加工時の振幅はパンチ 
Wrought

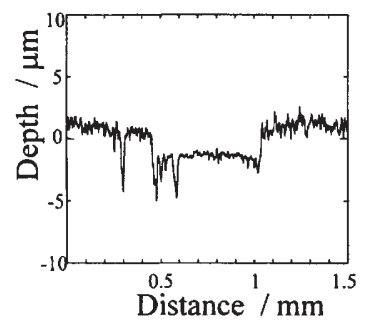

(a) $5 \mathrm{kN}$
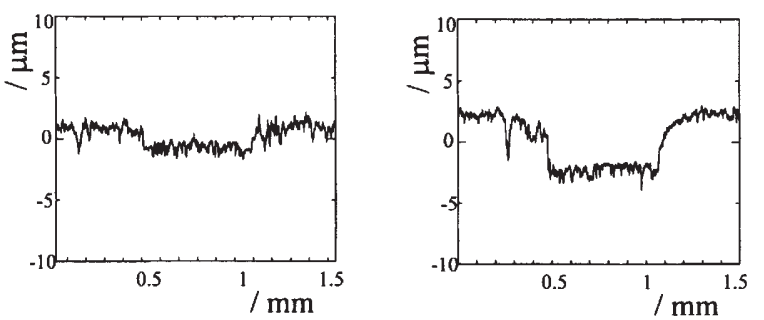

(b) $7.5 \mathrm{kN}$
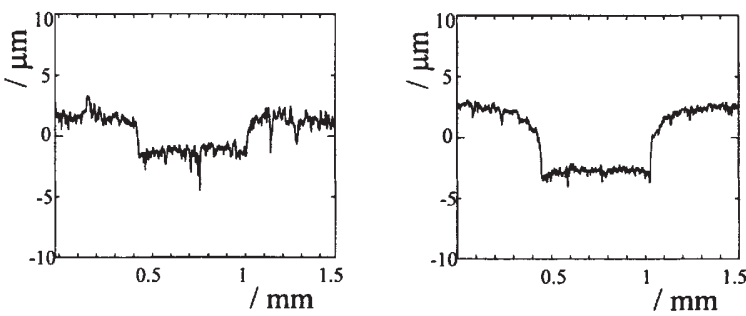

(c) $10 \mathrm{kN}$
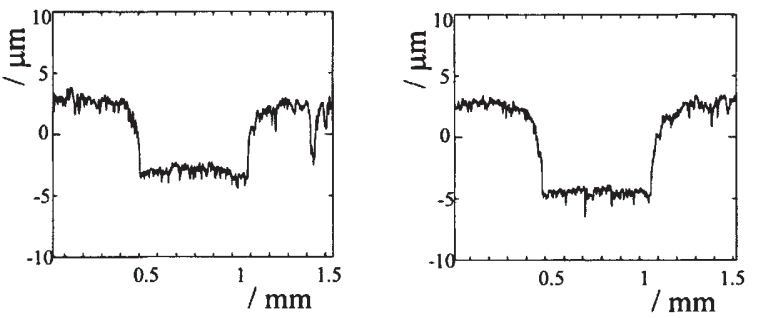

(d) $15 \mathrm{kN}$
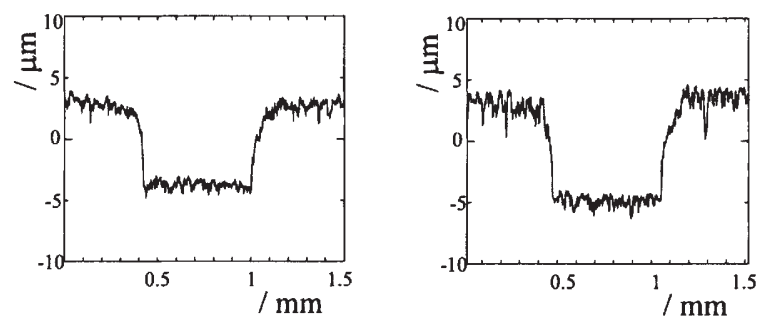

(e) $20 \mathrm{kN}$

Fig.11 Comparison of groove profiles in the indentation test with the ultrasonic vibration.

荷重の増加とともに減少する傾向にあり,そのため超音波振 動付加による圧印効果が抑制されるためである. 結果として 特に $5 \mathrm{kN}$ のとき増加量は約 $4 \mu \mathrm{m}$ と大きく, この段階で既に 目標値に達している．また，パンチ荷重が $20 \mathrm{kN}$ のきは超 音波振動を付加しても溝深さはほとんど変化しておらず, こ れは前述のように静的押达みだけで溝深さが平頭パンチ上の 微細突起の高さと同等になるためである. Fig.11の溝形状を Fig.9の静的押込みのものと比較すると, 同一パンチ荷重では 両素材とも超音波振動を付加することにより溝深さは増加し ており,特にパンチ荷重が最も低い $5 \mathrm{kN}$ とき素材によらず その傾向が顕著である.これは荷重が低いときの方がパンチ の超音波振動振幅が大きくなるためである. また, MIM材で は超音波振動を付加することにより溝肩部におけるだれ量が 若干減少する傾向にあった。

以上を要約すると, 同一加工条件下では MIM 材の方が溶 製材よりマイクロオーダーの微細溝の形状転写性は良好であ り,またパンチ荷重が低い方が超音波振動付加の効果が現れ やすいことが分かった. いずれにせよ, 本実験から当初の狙 いはある程度達成されたといえるようである。

\section{2 実験 -2}

まず, 実験-1において両方の素材に対し目標とする深さ 5 $\mu \mathrm{m}$ 以上の微細溝を成形できた $20 \mathrm{kN}$ 円弧パンチの押込み荷 重を設定し加工を行った. Fig.12(a)に加工後の素材の円周方 向断面における溝形状の測定結果を示す. 平均溝深さは溶製

Wrought

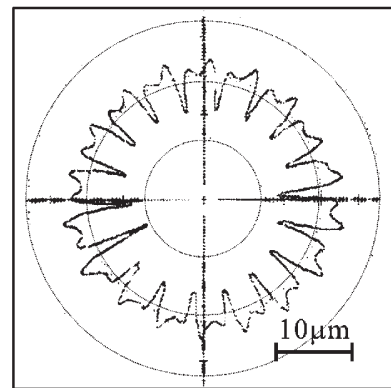

(a) $20 \mathrm{kN}$
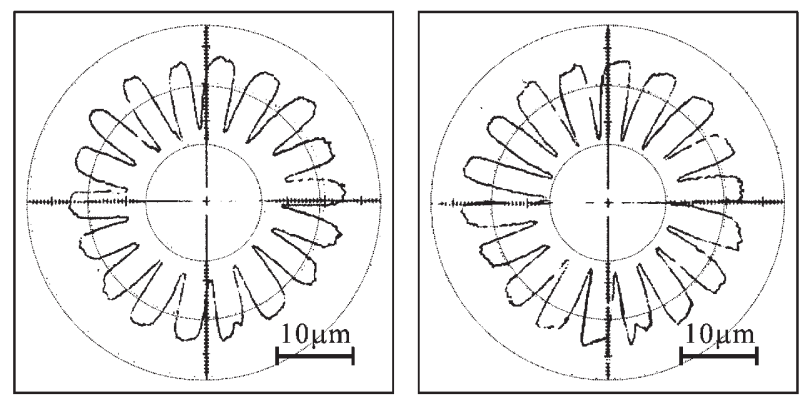

(b) $30 \mathrm{kN}$

Fig.12 Comparison of microgroove profiles between the wrought materials and the MIM materials. 
材で約 $6 \mu \mathrm{m}, \mathrm{MIM}$ 材で約 $9 \mu \mathrm{m}$ となっており，これらは実験-1 の静的押込みによる結果とよく一致している。しかし，溶製 材でもMIM材でも溝肩部にランダムな高さの隆起が発生し, その結果として㩐深さがばらついている.この隆起は円柱状 素材に工具が押し込まれるとき, 3 本の微細突起のうち特に 両端の突起によって素材が接触界面で円周方向にせん断変形 を受け，その結果，突起先端角部で素材が盛り上がりバリを 発生させることが原因であると思われる. 動圧軸受ではこの 種の隆起は動作時に焼付きの原因々なるので, その発生・成 長を極力抑制する必要がある.そこで, その抑制方法として, 加工中に隆起した材料を工具溝底部之接触させ押し潰す方法 を考え, パンチ荷重を $30 \mathrm{kN}$ まで増加させ同様の実験を行っ た. その結果を Fig.12 (b)に示す. 両素材とも溝深さのばらつ きが著しく減少し,ダイス肩部の隆起もほとんどなくなって いることから，本報で提案した単純押込みによる圧印加工法 が動圧スピンドル用ヘリングボーン微細溝の成形に適用でき る可能性が示唆された.

\section{4 結 言}

（1）実験-1の静的押込みの結果から, MIM 材は溶製材に比べ 形状転写性が非常に良好で, 同一パンチ荷重の場合, 成形 される溝深さは約 80\% 増加した。
（2）実験-1の超音波振動押込みでは，振動を付加することに より両素材とも溝深さは増加する傾向にあったが，特に パンチ荷重が最も小さい $5 \mathrm{kN}$ のときの傾向は顕著で あった。

(3) 実験-2の結果から, パンチ荷重が $20 \mathrm{kN}$ のきは両素材 とも溝肩部に隆起が発生し，その結果溝深さがばらつい た. ただパンチ荷重を $30 \mathrm{kN}$ と過大に設定すると, 加工中 発生した隆起が工具溝底部に接触し押し潰されるため, 問題となる隆起がほとんど消滅し, 溝深さのばらつきも 著しく小さくなった.

\section{文献}

1) E.A.Mujiderman, G.Remmers and L.P.M.Tielemans: "GreaseLubricated Spiral Groove Bearings", Philips technical review, 39(1980) 184-198.

2) Geiger, M.Kleiner, R.Eckstein, N.Tiesler and U.Engel: "Microforming", CIRP, 5(2001)445-466.

3) R.M.German: Powder Metallurgy Science, Metal Powder Industries Federation, (1994) 191.

4) S.H.Ike "Coining of surface microgeometry of combined cavities and projections", Advanced Technology of Plasticity 2005, (2005) 465-466. 